\title{
Décadas de militância: política e meio ambiente no depoimento de Caio Lustosa
}

\author{
Carla Simone Rodeghero' \\ Gabriel Dienstmann²
}

Em novembro de 2011, o advogado e ambientalista Caio Lustosa concedeu a entrevista que segue a dois pesquisadores da UFRGS (Carla Simone Rodeghero e Gabriel Dienstmann) envolvidos no Projeto Marcas da Memória: História Oral da Anistia no Brasil. O projeto foi proposto e financiado pela Comissão de Anistia do Ministério da Justiça e se desenvolveu em três universidades brasileiras (UFPE, UFRJ e UFRGS). O objetivo era contribuir para a montagem de um banco de depoimentos de pessoas que, durante a ditadura, foram atingidas pela repressão e/ou que se engajaram em diferentes formas de oposição ao regime. $\mathrm{O}$ material produzido pelo projeto será disponibilizado para consulta nas universidades mencionadas e no Memorial da Anistia, ainda em construção, em Belo Horizonte. A equipe da UFRGS realizou 18 entrevistas no estado do Rio Grande do Sul e chegou ao nome de Caio Lustosa por conta do propósito de contemplar variadas formas de militância e engajamento ao longo do período delimitado. Foi considerada a importância de se construir fontes de pesquisa acerca de movimentos da década de 1970, como o movimento pela anistia, o movimento

1 Doutora em História e professora do Departamento e do PPG em História da UFRGS. Atualmente realiza estágio de pós-doutorado no CPDOC da Fundação Getúlio Vargas.

2 Licenciado em História pela UFRGS e atua como pesquisador no projeto Memória Visual da Ditadura no Rio Grande do Sul, no Centro de Assessoria Multiprofissional - CAMP - em Porto Alegre. 
negro, o movimento pela terra, o movimento feminista, o ambientalista e o indígena. Em entrevista realizada com o Padre Arnildo Frtizen, na cidade de Carazinho, em 15 de novembro de 2011, ouvimos um relato sobre a luta pela terra que ganhou corpo no norte do estado a partir de um elemento detonador: o conflito ocorrido entre índios e pequenos agricultores na reserva indígena de Nonoai, em 1978. Na ocasião, cerca de 500 famílias de pequenos agricultores foram expulsas da reserva por índios kaingang, os quais tinham, desde os anos 1960, perdido a maior parte de suas terras para um projeto de colonização. Reforçou-se, então, a necessidade de ouvir pessoas que tivessem tido envolvimento com a questão indígena. Um dos caminhos foi buscar antigos militantes da Associaçáo Nacional de Apoio ao Índio, Anaí, entidade que sabíamos ter existido na segunda metade dos anos 1970. ${ }^{3}$ Uma pesquisa prévia apontou para o nome de Caio Lustosa, o qual poderia também nos falar a respeito da luta ambientalista no estado, tendo em vista sua larga atuação em tal campo.

Se a entrevista com Caio Lustosa nos oferece um panorama do surgimento, na década de 1970, dos novos movimentos sociais, da luta ambiental e da questão indígena, revela também uma rica trajetória política, que começa com a participação de seus pais na Revolução de 1923, passa pela sua participação nas campanhas do "Petróleo é nosso" e da Legalidade, e volta-se aos percalços trazidos pelo golpe de 1964 e pela ditadura para, finalmente, refletir sobre as questóes políticas e ambientais contemporâneas.

Conforme será visto a seguir, Lustosa, que desde 1966 trabalhava como Procurador do Estado do Rio Grande do Sul, participou da Agapan, Associação Gaúcha de Apoio e Proteção ao Ambiente Natural, criada em 1971, pelo agrônomo José Antônio Lutzenberger. A entidade surgiu no contexto do milagre brasileiro, das transformaçóes na agricultura, do aumento do uso de agrotóxicos. Era composta por agrônomos, biólogos, estudantes e outros profissionais. Preocupava-se tanto com o ambiente urbano quanto com o rural, mobilizando forças para denunciar a poluição, as podas desordenadas das árvores ou a sua derrubada para a abertura de novos empreendimentos urbanos, o tratamento dos esgotos domésticos

3 A Anaí era uma das entidades que participavam do Comitê Brasileiro pela Anistia, criado em Porto Alegre, em abril de 1978. De acordo com RODEGHERO, Carla S.; DIENSTMANN, Gabriel; TRINDADE, Tatiana. Anistia ampla, geral e irrestrita: história de uma luta inconclusa. Santa Cruz do Sul: Editora da Unisc, 2011. 
e industriais, a exploração de recursos minerais, a produção e o uso de agrotóxicos etc. A entrevista de Caio Lustosa contém mençóes a diversas campanhas pioneiras na luta ambientalista no Rio Grande do Sul: o caso da Borregaard, uma fábrica de celulose instalada no município de Guaíba, separado de Porto Alegre pelo Rio/Lago Guaíba, cujo mau cheiro impregnava a capital gaúcha; o caso dos dejetos do Polo Petroquímico de Triunfo, que seriam jogados nas águas da Lagoa dos Patos sem tratamento; a questão do controle dos agrotóxicos; a questão da exploração de granito rosa no futuro Parque Estadual de Itapuã.

Sobre a inserção de Caio Lustosa nas lutas e nos debates a respeito das questóes indígenas, destacamos que em 1976 ele participa da fundação e se torna presidente da Anaí, entidade com importante atuação na luta pela defesa das terras indígenas e contrária aos projetos governamentais de encampar as reservas e integrar forçosamente os índios na sociedade, ignorando direitos, aspectos culturais e a autonomia destes. $\mathrm{Na}$ entrevista, Lustosa aborda o conflito entre índios e colonos na reserva de Nonoai, a mediação realizada por setores vinculados à Igreja Católica, a atuação da Funai e a politização da luta durante a década de 1980, o que é simbolizado numa situação em que, como advogado, Lustosa defende o direito do cacique Mário Juruna de participar de um congresso no exterior contra a vontade do governo brasileiro.

Associado às lutas ambientalistas e indígenas, Caio Lustosa teve atuação política também em outros campos. Defendeu presos políticos; teve pequena atuação como advogado trabalhista; como vereador de Porto Alegre pelo PMBD, entre 1983 e 1988, propôs projetos pioneiros na questáo ambiental; como Secretário do Meio Ambiente do Município de Porto Alegre, durante a primeira gestão do Partido dos Trabalhadores, participou da elaboração de um decreto que proibia a comercialização, o uso e o transporte dos agrotóxicos que faziam parte da "dúzia suja", por serem altamente prejudiciais à saúde humana. Caio Lustosa continua ainda hoje com uma ativa militância política centrada na defesa do meio ambiente. Em relação às questóes ambientais contemporâneas, refere-se, em sua entrevista, às grandes barragens, a um projeto de desenvolvimento, "de crescimento a todo custo, (onde) o negócio é produzir. O país precisa de energia, investe na indústria automobilística, investe nessa especulação imobiliária nas cidades. Esse horror!”

A entrevista, em seu conjunto, dá a conhecer a trajetória de um cidadáo que, aos 78 anos de idade, dispóe-se a relatar a experiência vivida e a refletir 
sobre ela, acreditando no potencial educativo desse trabalho. Tal potencial já vinha sendo explorado a partir de outra iniciativa de memória protagonizada por Lustosa que, em 2011, lançou o livro A luta ambiental e cidadania: da Borregaard e outros episódios, escrito em parceria com a jornalista Eva Benites.

\section{Transcrição da entrevista4}

Gabriel Dienstmann - Boa tarde. Hoje é dia 22 de novembro de 2011, estamos realizando mais uma entrevista do projeto Marcas da Memória História Oral da Anistia no Brasil. Fazem parte da equipe a Professora Carla Rodeghero e eu, Gabriel Dientsmann. Estamos aqui, hoje, entrevistando o Dr. Caio Lustosa, e vamos dar início à entrevista.

Então, primeiramente, gostaríamos de agradecer a sua disponibilidade em nos dar essa entrevista, Dr. Caio Lustosa, e nós gostaríamos de começar perguntando para o senhor falar um pouco sobre a sua infância e a sua família. Onde é que o senhor nasceu? Em que ano? De que forma sua família influenciou você politicamente?

Caio Lustosa-Bom, eu sou natural de Caxias do Sul, eu nasci lá em [19]33, portanto estou com 78 anos. Meu pai era pernambucano, veio para cá no início do século XX, era formado na Faculdade de Direito de Recife. Inclusive foi colega do Augusto dos Anjos, aquele poeta famoso. Ele veio para cá, primeiro foi promotor público lá em São Luiz Gonzaga, onde conheceu a minha mãe, que era da família Pinheiro Machado (ao fundo toca um relógio), sobrinha do Senador Pinheiro Machado. Eu nasci, portanto, lá em Caxias, quando ele, depois de uma longa atuação como promotor e editor de um jornal lá em São Luiz, e depois deputado aqui [Porto Alegre], inclusive era da geraçáo do Getúlio, conviveu muito com Getúlio Vargas. Depois, em [19]27, ele ingressou

4 LUSTOSA, Caio. Entrevista concedida a Carla Simone Rodeghero e a Gabriel Dienstmann, em 22 de novembro de 2011, em Porto Alegre, RS, para o Projeto Marcas da Memória: História Oral da Anistia no Brasil. Montagem do roteiro e gravação da entrevista: Gabriel Dienstmann; tratamento digital dos arquivos: Ricardo Eusébio Valentini; transcrição: Diego Scherer da Silva e Ricardo Eusébio Valentini; revisôes: Dante Guimaraens Guazzelli, Carla Simone Rodeghero e Caio Lustosa. A entrevista está disponível para consulta no Núcleo de Pesquisa em História da UFRGS. 
na magistratura e eu nasci em Caxias, onde ele era juiz de direito. Ele tinha uma formação filosófica, como quase toda a sua geração lá da Faculdade de Recife, uma formação positivista, ele era positivista. A minha mãe, por sua vez, era missioneira lá de São Luiz, tinha uma religiosidade, assim, não muito ortodoxa, mas era católica, cristã. Bom, eles, nos anos de [19]23, ambos participaram da Revolução, liderada por Assis Brasil, para depor o Presidente de Estado, Borges de Medeiros, que já estava há 25 anos no governo. Minha mãe, inclusive, sob o manto da Cruz Vermelha, ela participava da Cruz Vermelha, mas carregava armas para os revolucionários lá do outro lado de Guaíba, liderados por Zeca Netto. Então, eu sempre fui criado assim, com toda essa informação sobre a atuação deles, de certa rebeldia contra as injustiças, contra os desmandos. Daí foi minha formação de curso primário, foi em São Leopoldo, depois estudei no IPA [Instituto Porto Alegre] aqui.

Carla Rodeghero - Primeiro com os jesuítas em São Leopoldo?

CL - Não, colégio público, a escola Visconde de São Leopoldo, colégio estadual. Depois aqui no IPA, com os metodistas. Ali, já no IPA, nos anos [19]50, eu fui sensibilizado pela campanha a favor da Petrobras e do "Petróleo é nosso". Participei e ali comecei a militar, já no curso secundário.

GD - Teve aproximação com o PTB então?

$\mathbf{C L}-$ É, mais tarde eu entrei na ala moça do PTB e militei ali até um pouco antes de [19]64. Um pouco antes de 64 eu estava meio desgostoso com a (pausa), com o comportamento do partido e das lideranças, e daí fui para o Partido Socialista. Quando deu o golpe de 64, eu já estava no Partido Socialista Brasileiro.

CR - O Partido Socialista era forte aqui em Porto Alegre?

CL - Não, era muito fraco.

CR - Quem fazia parte dele?

CL-Tinha... A maior liderança era o Cândido Norberto, e um dos dirigentes era o Germano Bonow, pai desse deputado, Germano Bonow Filho. 
CR - Pedro Alvarez não fazia parte?

CL - Pedro Alvarez também fazia. Bom, daí, então, agora nós vamos para...

GD - Voltando um pouquinho à campanha do "Petróleo é nosso", como é que foi vivenciar esse período?

CL - Foi bastante intensa, havia muita mobilização, foi muito interessante...

GD - Você era secundarista?

$\mathbf{C L}-\hat{E}$, foi como secundarista que eu participei disso.

GD - Houve manifestaçóes de rua, assim?

$\mathbf{C L}$ - Havia, sim, manifestações de rua, reunióes, debates. E havia um grupo muito forte dentro do Exército que era a favor, o general Horta Barbosa, Estilac Leal e outros. E depois, com [o golpe de] 64, eles foram alijados, mas era um grupo nacionalista e a favor do monopólio estatal do petróleo.

CR - O suicídio de Vargas, o Senhor estava ainda no secundário?

CL - A essa altura, no suicídio de Vargas, eu já estava entrando na Universidade. Eu fiz dois vestibulares, de direito e jornalismo, e eu atuava muito no Centro Acadêmico e no dia do suicídio de Getúlio eu estava no prédio da Faculdade de Filosofia, aí no campus central. O curso de jornalismo era ligado à Faculdade de Filosofia antes. Hoje é um curso à parte.

CR - E aí houve muita gente nas ruas?

$\mathbf{C L}-$ É, aqui mesmo neste bairro, aqui, Bom Fim, houve depredações por parte da população. Inclusive o tenente do Exército, que era jovem até, filho de uma família conhecida nossa, fuzilou, metralhou uns operários ali em frente ao [Hospital] Pronto Socorro, nesse dia, 24 de agosto de 54.

CR - O Senhor sentiu muito a morte de Vargas?

$\mathbf{C L}-E ́$, a gente, ele sentiu. Meu pai, por exemplo, se derramou em lágrimas, porque eles tinham sido contemporâneos lá em São Luiz, quando meu pai 
era promotor e o Getúlio era advogado lá no foro de São Luiz, vinha de São Borja para São Luiz, conviveram muito. Depois, na Assembleia aqui também, meu pai foi deputado junto com ele, e os dois tinham uma amizade que vinha de antigo. Durante o Estado Novo não, daí meu pai não tinha muita relação próxima a ele.

CR - O fato do seu pai e sua mãe terem lutado contra o Borges [de Medeiros] em [19]23, e depois o Senhor ter se filiado ao PTB, não tem... Como é que houve essa transição? Por que o PTB é herança do Vargas, que por sua vez tem suas relaçóes com os republicanos?

CL - É, é, mas eu tinha muita... Eu, a essa altura, era de uma ala dentro do PTB que era mais alinhada com o Pasqualini, Alberto Pasqualini, que tinha, inclusive, o Pasqualini, havia criado mesmo durante o Estado Novo a União Social Brasileira, que era um movimento assim... O Pasqualini não chegava a ser um homem de esquerda, mas era um cara progressista, então... E eu sempre me alinhei mais... Havia o grupo do Brizola, que logo foi sendo hegemônico no Partido, mas eu sempre me alinhei mais com o pessoal que vinha da vertente liderada pelo Pasqualini. O economista, que depois foi deputado, Temperani Pereira, e outros, Unírio Machado, que era um pessoal mais ideologizado, assim. A turma do Brizola era o populismo, não é, dentro do PTB, e eu sempre fui, logo já fui mais radical nessa história de ideologia.

GD - O Senhor chegou a ter alguma atuação no governo do Brizola aqui no Rio Grande do Sul?

CL - Não.

GD - E no episódio da Legalidade?

CL - No episódio da Legalidade, eu estava, eu fiz parte do Mata-borrão, um comitê de resistência democrática que era sediado no Mata-borrão. ${ }^{5}$ $\mathrm{Eu}$, junto com o advogado Vitor Nuńez, que ainda existe, Vitor Douglas

5 Pavilhão de Exposiçóes do Governo do Estado do Rio Grande do Sul, situado no centro de Porto Alegre. O local serviu como ponto de articulação de Comitês de Resistência em apoio à posição defendida por Leonel Brizola, no sentido de garantir a posse do vice-presidente, João Goulart. 
Nuñez e outros, eu ali fazia, me aproveitando do curso de jornalismo... Não, foi bem antes. Mas eu fazia as palavras de ordem para serem divulgadas nos alto-falantes, essa história toda, as panfletagens, as faixas. Havia um grupo de artistas também, entre os quais o Danúbio Gonçalves, esse grande artista plástico, e o Xico Stockinger, e eles lideraram um grupo de artistas que faziam faixas e cartazes, nos altos do Mercado [Público], e ali eu também ajudava naquela coisa. Isso no episódio de sessenta, na queda do Jânio Quadros...

CR - [19]61.

CL $-[19] 61$.

CR - Nessa época, o Senhor estava já formado em direito?

CL - É. Eu estava formado jornalista em [19]58 e em direito em [19]60. Inclusive, um fato meio, que eu digo de sorte, mas que me marcou foi a... Havia a formaçáo de uns pelotóes de operários e eu cheguei a dar ordem no ninho da cruz, para os motorneiros e condutores da Carris. ${ }^{6}$ Ali em frente à Faculdade de Medicina, a gente fazia, treinava. Porque havia a perspectiva de um movimento armado, inclusive haveria uma resistência. Então, como eu havia tirado o curso para sargento da reserva em [19]52, eu ainda entendia um pouco de armamento e dessa coisa, essa capacitação militar.

GD - E depois, posteriormente, no governo João Goulart, como é que o Senhor vivenciou o período da presidência do Jango?

CL - A gente ficou naquela expectativa, inclusive muitos, até eu na época, achávamos que devia ter havido uma resistência. Hoje a gente acha, compreende que qualquer resistência ali seria esmagada, porque havia a ameaça de as tropas americanas, estavam vindo, próximas, prontas para desembarcar, haveria uma guerra civil muito intensa.

CR - O Senhor chegou a ir para frente da prefeitura?

6 Empresa responsável pelo transporte público urbano em Porto Alegre, que era feito, até 1970, por bondes.

7 Dado o golpe, muitas pessoas se dirigiram à frente da Prefeitura de Porto Alegre, então ocupada por Sereno Chaise, prefeito eleito pelo PTB. A multidão esperava ordens para organizar a resistência, o que 
$\mathbf{C L}-\mathrm{Sim}$, a gente participou de tudo isso.

CR - Como era o clima naqueles dias em que não se sabia qual ia ser a posição do Jango?

$\mathbf{C L}-$ É, havia uma expectativa, tanto é que o dia em que o Jango anunciou que ia aceitar o parlamentarismo [durante a crise da Legalidade, em 1961], havia, houve, assim, uma decepção, porque o povo estava todo empolgado achando que tinha que empossá-lo como presidente, sem restriçôes, e não um governo parlamentarista. Houve uma água na fervura dentro do partido, a massa popular lá ficou muito... Tanto é que ele foi vaiado nesse dia em frente ao Palácio [Piratini]. ${ }^{8}$

GD - Como é que o Senhor vivenciou o período do golpe mesmo? 31 de março, $1^{\circ}$ de abril?

CL-Bom, daí, em [19]61 mesmo, eu tinha uma bolsa para a Europa e fiquei um ano lá na França estudando um pouco. E depois, quando eu voltei, eu voltei em fim de [19]62, por aí, [19]63, e daí já a situação começou a ficar muito tensa, com aquelas manifestaçôes, greves, e os sargentos do exército também mobilizados, e redundou depois no golpe de [19]64.

CR-O que o Senhor estava fazendo no dia do golpe? Onde o Senhor estava? $\mathrm{Ou}$, como ficou sabendo que estava em curso um golpe?

CL - No dia do golpe foi assim: eu, naquela noite de 31 [de março] para $1^{\circ}$ [de abril], estava se instalando ali naquele edifício Bier Ullmann [ao lado da nova prefeitura, no centro de Porto Alegre] um curso de formaçáo de alfabetizadores segundo o método Paulo Freire (toca ao fundo um relógio), e era ministrado por aquele sociólogo, Seno Cornelli, não sei se conheceu.

não chegou a acontecer. O próprio Sereno foi preso imediatamente após o golpe e teve seu mandato cassado. Sobre o tema, ver: Chaise, Sereno; Klöckner, Luciano. O diário político de Sereno Chaise: 60 anos de história. Porto Alegre: AGE, 2007.

8 A pergunta, na verdade, referia-se à posição de Jango quanto a resistir ou não ao golpe de 1964 . $\mathrm{O}$ entrevistado, no entanto, retomou o raciocínio a respeito do movimento da Legalidade, quando Joáo Goulart teve que decidir se aceitava a emenda parlamentarista ou se insistia na posse sob o regime presidencial, conforme era defendido por Brizola e por seus apoiadores. 


\section{CR - Luciano?}

CL - Seno Cornelli. E eu tinha, estava inscrito nesse curso, assisti e quando saímos da primeira aula, da abertura do curso, já se sabia que havia, que o golpe estava em andamento, tanto é que eu saí dali, naquele tempo eu tinha um, aquele carrinho Dolfini, da Renault, e apareceram uns companheiros do Partido Trabalhista ali, e a gente rumou lá para o aeroporto, porque o Jango estava se deslocando para cá. E lá no aeroporto, inclusive, eu presenciei, estava o Brizola e o general...

\section{CR - Ladário?}

CL - Ladário Teles, que... E fiquei assim ao lado, estava o Brizola caminhando, era uma noite bastante fria, apesar de março, e o general, esse com japona verde e tal. E eu vi os dois ali em um diálogo bem intenso. Aí pelas tantas... E a coisa foi se prolongando, a chegada do Jango demorou, ele foi chegar mais tarde, e lá pelas tantas, nós, eu, por exemplo, me recolhi. Aí, no outro dia que eu fiquei sabendo o desfecho, o Jango foi para a casa do General e lá resolveu sair do país.

GD - De que forma o golpe e a inserção da ditadura modificou a sua militância política? Impactou, influenciou?

CL - Sim, daí se tornou impraticável qualquer militância, inclusive eles acabaram fechando os partidos, todos, daí não havia... Então, eu fui... Eu não sofri, assim, uma prisão, uma repressão pessoal, assim, mais dura, como muitos outros. Daí eu me dediquei, inclusive eu tinha sido colega do Carlos Araujo, que depois veio a ser esposo da Dilma, presidente, e o Carlos Araujo, no tempo de faculdade, antes do golpe, é claro, nós participamos organizando, tentando organizar aqui as Ligas Camponesas, aí no interior. Viajei algumas vezes com ele, aí mais tarde, depois que deu o golpe, um dia ele me convidou para partir para a luta armada. Mas como eu náo tinha, assim, vocação guerrilheira, eu disse: "não, eu não vou". Não fui, mas daí fiquei me dedicando ao meu trabalho como advogado, e passei a defender perseguidos políticos, inclusive dois que eu mais me lembro é o Alfredo Nery Paiva, ele é pai de um historiador, Marcelo Paiva, até o mesmo nome daquele escritor, Marcelo Paiva. Esse rapaz é historiador hoje, é professor de história, não sei 
se historiador, professor de história no Colégio Bom Conselho. E o Alfredo tinha sido meu colega, o pai dele, no jornalismo, era um cara muito inteligente, preparado politicamente, e acabou... O Alfredo foi preso depois, logo depois do golpe, torturado, muito torturado aí pelo delegado Pedro Seelig, no DOPS, e a mulher dele também. Eles foram colegas no jornalismo, meus colegas, e apelou para mim para eu interceder, para ver se entrava com alguma medida judicial para libertá-lo, ou mesmo para livrá-lo da tortura. Eu fui, intercedi por ele através de um amigo do delegado, aquelas coisas, porque a justiça estava completamente impraticável, náo funcionava. Aí, depois de um tempo, ele foi solto. Daí ele saiu, isso já era lá pelo ano de [19]73, [19]74. Tanto é que [quando] eles saíram daqui, tinha havido a Revolução dos Cravos em Portugal, eles foram para lá, e havia também a emancipação das colônias africanas. Aquela guerra colonial tinha terminado com a revolução, e eles foram trabalhar em Moçambique. Ambos eram professores de, ele mais que ela, que era a Carmen Sílvia, professora de literatura brasileira.

CR - E eles tinham alguma participação em alguma organização clandestina?

CL - Não, eles foram... O Alfredo, antes disso, ele foi naquela guerrilha lá de Vale da Ribeira, ele participou ali e nisso que ele foi preso. Quando ele voltou aqui, prenderam ele, prenderam e torturaram. E esse foi um dos que eu...

CR - Aí o Senhor conseguiu tirá-lo do DOPS, ele chegou a ser processado na justiça militar também ou foi só o inquérito?

CL - É, eu não me lembro, eu acho que ele não chegou a ser condenado, ou se foi, foi à revelia, porque logo em seguida ele viu que a situação dele estava ruim e ele foi embora para Portugal. E outro foi o Djalmo Oliveira, que agora eu fiquei sabendo que faleceu também. Esse eu atuei junto lá na Justiça Militar, no processo que estava sendo movido contra ele por subversão. Ele era ligado ao Partido Comunista. E aqui eu dei abrigo para o Antônio Apoitia Netto, que hoje é advogado lá em Santana [do Livramento]...

CR - Como chama?

CL - Antônio Apoitia Netto. Ele era líder bancário, muito atuante na época, e foi muito perseguido. Ele morava ali no fim da [Avenida] Osvaldo Aranha, 
no início da, perto da entrada para o túnel, em um apartamento ali. E daí, quando ele viu que a coisa estava feia, ele se homiziou aqui em casa. Daí, em um dia que ele saiu, ele foi lá e prenderam, aquela coisa, não é?

CR - Havia mais advogados que se dispunham a lidar com os presos políticos? A atender os presos políticos?

CL - Havia, mas muitos cobravam, para muitos a coisa era remunerada. Eu sei de um que cobrava muito, mas eu não vou dizer o nome para não...

CR - Sem nenhuma necessidade...

GD - O Senhor chegou a receber alguma ameaça como advogado de preso político?

CL - Não, não cheguei a ser. $\mathrm{O}$ pessoal às vezes me pergunta como é que eu sempre atuando assim, eu não fui preso, nem processado, nem cassado. Daí me contaram mais tarde que eu... Lá pelos anos [19]60, eu participava de um chamado "Clube Nordestino", que é um clube integrado com gente do Nordeste, e como eu era filho de pernambucano, eu entrei nesse clube aqui, que era na [Avenida] Getúlio Vargas, e ali fizemos várias promoçóes e inclusive bailes carnavalescos, conferências. Trouxemos o Gilberto Freire, o Ascenso Ferreira para fazer palestra ali, aqui em Porto Alegre. E havia um general, o general Guilherme César da Silva, que era nosso companheiro. Esse general, ele era daqueles generais linha dura desde os anos [19]30, ele já havia sido contra a Revolução de [19]30, ele ficou fiel ao governo do Washington Luís. E depois me disseram, depois dessa história toda... Eu me intrigava "como é que os caras nunca me convocaram?". Aí eles disseram que quando houve a lista de cassaçóes, esse general teria tirado a minha ficha e de mais dois companheiros que eram de certa forma de esquerda, e ele tinha tirado: "não, deixa aqui comigo" e ele teria nos livrado. Eu nunca pude comprovar [isso] porque ele faleceu. Não sei se foi assim, não é? Salvo pelo gongo.

CR - O Senhor chegou a entrar algumas vezes no DOPS?

CL - Sim. 
CR - Chegou a ver alguma coisa do que geralmente se denuncia, das torturas?

CL - Não, eu só tive acesso ao gabinete do delegado Pedro Seelig, quando eu fui interceder por esse rapaz, o Alfredo, mas lá náo. Primeiro, porque eles não permitiam o acesso.

GD - E quais eram as dificuldades, obstáculos que, como advogado, o Senhor encarava para combater a perseguição política e tentar...

$\mathbf{C L}$ - Ah, era praticamente a Justiça Militar. Ela, apesar de ter um auditor que era civil, até faleceu há não muito tempo, os julgadores ali eram oficiais do Exército. Então, praticamente era impossível conseguir a absolvição de alguém ali, era muito, a coisa era muito rígida. Era baseada na Lei de Segurança Nacional, então era muito difícil. Até houve um episódio interessante comigo. Deixa eu ver: em [19]60, eu fiz concurso para advogado de ofício, que hoje é Defensor da Ativa, depois passei mais tarde a Procurador do Estado, em [19]66. E lá em [19]66, não, nos anos [19]70, eu fui com um jurista, [que] inclusive foi presidente do Supremo Tribunal, José Nery da Silveira - pai de um promotor aqui da Justiça Federal, do Ministério Público Federal, o José Nery, que tinha sido nosso Consultor Geral do Estado. Ele me requisitou para trabalhar na Justiça Federal como defensor lá, das pessoas sem recursos, e ali eu ouço um episódio interessante: havia um assaltante, chefe de uma ganguezinha no centro, que era chamado Pinguim, e ele recrutou uma turma de gurizotes, assim, não sei como fez relação, gente até que não precisava, inclusive o filho de um deputado da Assembleia, e assaltaram um banco. Foram todos presos depois. Aí, esse processo de assalto a banco era considerado dentro da Lei de Segurança Nacional, e eles foram processados na Justiça Militar, e o filho desse deputado também. Daí, o irmão desse rapaz, que trabalhava na Justiça Federal, veio me apelar para eu defendê-lo na Justiça Militar. Eu defendi, o rapaz ficou preso algum tempo, mas logo... Agora o Pinguim foi condenado, o outro foi absolvido [risos]. Não foi absolvido, mas foi condenado a uma pena mínima, de um ano, assim.

CR - O Senhor tinha alguma participação na $\mathrm{OAB}$ nesse período? A OAB se manifestava em relação à ditadura? 
CL - Sim. Eu participei de todas aquelas, dos Congressos da OAB, e várias atividades aí que a gente mantinha, inclusive depois, na campanha da Anistia, mais tarde.

GD - Mas, e o concurso que o Senhor estava falando, de procurador, o Senhor chegou a fazer? Foi aprovado?

CL - É, eu fiz o concurso em [19]66 e ali...

GD - E o Senhor passou?

CL - Passei e fui nomeado... Antes, eu tinha tentado concurso para promotor público. Daí foi cassada minha inscrição e não me deixaram fazer o concurso por razóes ideológicas. Eu sei que o Procurador Geral da Justiça mandou buscar nossas fichas e tinha minha ficha no DOPS, e eles não me deixaram fazer o concurso. Inclusive, mais tarde, uma colega, que está aposentada também, quando foi fazer e também barraram, e ela teve que entrar com mandado de segurança para conseguir ser nomeada. E ali eles me barraram, me barraram no Ministério Público, mas no concurso de advogado de ofício eles não fizeram essa triagem, no meu concurso. No concurso seguinte, dessa colega, já começou a triagem (ao fundo toca um relógio).

GD - Depois da década de [19]60 o Senhor teve aproximação com algum grupo de oposição à ditadura?

CL - Depois de quê?

GD - Depois de, na década de [19]60 ainda, após o golpe, o Senhor teve alguma aproximação com...

CL - Eu estava sempre entrosado com o pessoal, não é? Reuniōes e tentando entender aquela conjuntura, ver o que ia se fazer e tal.

GD - E como é que se deu a sua aproximação com grupos de defesa de direitos indígenas e de questóes ambientais, como é que se deu isso?

$\mathbf{C L}-\hat{E}$, isso foi ali... Bom, a primeira, a minha participação começou na questão ambiental. Eu me engajei na Agapan [Associação Gaúcha de Proteção ao Ambiente Natural] em [19]70, logo que foi criada, em [19]72,[19]71... 
GD - [19]71, com o [José] Lutzenberger?

$\mathbf{C L}$-É. E aí, antes de eu entrar na Agapan, eu, assim, voluntariamente, quixotescamente, eu entrei com uma queixa-crime, que houve aquele episódio da [empresa] Borregaard. A cidade ficou tomada com o mau cheiro da celulose, um horror. E daí eu ingressei com uma queixa-crime contra os diretores da Riocell, da Borregaard, na época. E essa queixa-crime não foi... Eu pedi para o Ministério Público processar e o Ministério Público se recusou, o juiz também não aceitou. Daí eu recorri para o tribunal, daí chegou no tribunal, eles me disseram que a poluição atmosférica e hídrica era lá em Guaíba, que eu tinha que tentar em Guaíba (risos), vieram com essas alegaçóes, assim, jurídicas que... Eu sei que esse processo, inclusive negado, disseram que o resultado dele deu em Guaíba porque lá que tinha que ser feito o processo e não aqui [Porto Alegre]. Mandaram para Guaíba o processo e nunca foi julgado. E, inclusive, na época desses episódios, o governo, para dar força para esse grupo norueguês, nomeou o comandante do $3^{\circ}$ Exército. $\mathrm{O}$ comandante do $3^{\circ}$ Exército saiu daqui - o general Breno Borges Fortes - e foi nomeado diretor administrativo lá da firma. No dia em que ele assumiu, inclusive, houve desfile de tropas militares. É aquela coisa do complexo militar e industrial que já o [John Kenneth] Galbraith já denunciava nos Estados Unidos, o próprio Eisenhower já denunciava isso, esse fenômeno da aliança dos grupos econômicos, da indústria, da grande indústria com os grupos militares.

CR - E havia outras entidades ou pessoas que nessa época já começavam a se manifestar contra essa poluição?

$\mathbf{C L}-$ Ah, houve, houve. Eu tive a sorte que essa poluição, principalmente o mau cheiro, afetava muito áreas de criação de cavalos do diretor, do Breno Caldas, que era diretor do...

\section{CR - Correio.}

CL - Correio do Povo. Então, ele me deu assim um espaço, eu tenho até hoje os recortes, as minhas petiçóes todas, página inteira ele publicava, inteira. Aquilo ali foi muito bom, tanto o Correio como a Folha [da Tarde] me deram... Claro, pelo lado tinha também o interesse dele, mas do ponto de vista geral foi muito bom. 
GD - Mas era um período, digamos assim, pioneiro da luta ambiental?

CL - É, foi logo no início. Logo em seguida, então, eu vi que sozinho eu não ia poder fazer nada, foi então quando o Lutzenberger, o [Augusto] Carneiro, a Hilda Zimmermann e outros criaram, fundaram a Agapan, e daí comecei a me entrosar com a Agapan, daí foi toda a luta que, inclusive (bate em um livro na mesa), está contada aqui nesse livro. ${ }^{9}$

GD - Que atividades a Agapan desenvolvia? Como é que era a atuação?

CL - Era uma atividade constante, porque esse processo de poluição e degradação ambiental era de todo o jeito, tanto na cidade quanto no interior, nós tivemos muitos... A luta, essa da Borregaard, depois a do Polo Petroquímico, em [19]79. Que o governo queria lançar os dejetos do Polo todos na Lagoa dos Patos, sem tratamento. Fizemos uma manifestação, assim, que veio de, começou em Viamão e foi até Rio Grande. A gente fazia grupos de cavalarianos, CTGs [Centros de Tradiçóes Gaúchas], clubes de mães, mobilizamos, foi muito interessante essa luta. Até conseguimos um deputado, o deputado Lélio Souza, do PMDB, que apresentou uma emenda no projeto de implantaçáo do Polo, obrigando a tratarem os dejetos lá dentro em uma estaçáo, a tal estação de Sistema de Tratamento de Fluídos Líquidos, Sistel, lá dentro do Polo.

GD - E como é que essa questão ambiental era tratada na ditadura? Havia uma abertura, um espaço para se debater essas questóes?

CL - Não, nós nos reuníamos ali no edifício da Rua da Praia, onde funcionava o Clube dos Orquidófilos. Então, todas as segundas-feiras havia uma plenária ali. Mas nós éramos vigiados, tinha um cara lá que a gente sabia que era olheiro e que estava sempre ali para fazer os relatórios e dizer como era que a coisa ia.

CR - Isso a partir de [19]72?

$\mathbf{C L}-\hat{E}$.

9 O entrevistado está se referindo ao livro Luta ambiental e cidadania: da Borregaard a outros episódios, escrito em parceria com Eva Benites e publicado pela Livraria Palmarinca, de Porto Alegre, em 2011. 
GD - E como é que essa discussão permeava também outros grupos de oposição à ditadura? Como é que havia, havia um diálogo entre vocês com outros setores?

CL - Com outros setores...

GD - De resistência, de lutas pela liberdade democrática?

CL - É, também foi criado na época, aliás, já vinha de antes, a Ação Democrática Feminina Gaúcha, liderada pela Dona Magda Renner. Mas essa Ação Democrática Feminina Gaúcha era ela, ela participou ativamente do golpe da ditadura...

CR - Ela foi favorável ao golpe?

CL - É, foi favorável ao golpe, inclusive aquele livro do Dreifuss, 1964 , consta. Elas participavam, a gente chamava as mulheres de marchadeiras, elas eram o grupo das... Mas foi muito interessante essa evolução depois que elas sofreram. Vendo os problemas ambientais, essa, elas foram tomando outra, outra visão do mundo, a Magda Renner...

CR - Essas mesmas mulheres?

$\mathbf{C L}$ - É. Tanto é que um dia elas denunciaram, fizeram uma denúncia: a Volkswagen tinha uma área grande lá no Centro-Oeste ou no sul da Amazônia, o tal de Vale do Cristalino, e a Volkswagen resolveu meter fogo naquilo, foi um crime ambiental tremendo, tanto é que foi detectado pelo próprio satélite, um satélite. E elas botaram a boca no trombone, fizeram uma denúncia direta para o Geisel na época e eu sei que daí elas foram ameaçadas de processo de calúnia e difamação pelo Wolfgang Sauer, que era o chefão da Volkswagen em São Paulo, mandou ameaçá-las de processo. A família Renner até me convocou para uma reunião, que como advogado, o que eu podia fazer. [Eu disse:] "Deixa processar, nós vamos alegar que o grande crime era eles que estavam cometendo".

CR - E que pessoas participavam da Agapan? Eram mais estudantes?

CL - É, muitos estudantes, pessoal ligado à área ambiental, agrônomos, biólogos, pessoal da... 
CR - Era uma época onde a agricultura brasileira estava passando por muitas transformações também...

CL - É, é. Houve aquela investida para o agronegócio lá, que hoje assume proporçóes enormes, e que, inclusive isso daí teve reflexo na questáo do indígena. Porque começaram a invadir as áreas indígenas e sacrificar e matar índios lá. Foi quando, em 76, nós criamos a Anaí [Associação Nacional de Apoio ao Índio], aqui em Porto Alegre.

CR - O Senhor pode falar um pouco então sobre essa entidade?

CL - Anaí, é. Em [19]76, meados de, talvez antes um pouco, a crise das populaçóes indígenas estava se avolumando. Houve então várias denúncias por parte da Igreja, dos antropólogos de São Paulo e da OAB também. E aqui, a gente, dois companheiros, o Assis Hoffman e o Antonio Hohlfeldt, resolveram fazer um seminário que se intitulou "O índio brasileiro: um sobrevivente?”. Esse seminário foi muito bom, se debateram todas essas questôes e em decorrência desse seminário se criou a Anaí, Associação Nacional de Apoio ao Índio, para tentar dar certo respaldo, inclusive na área jurídica, algumas açóes para impedir essas barbaridades que estavam ocorrendo tanto aqui no estado como no Centro-Oeste, na Amazônia.

CR - E a entidade teve abrangência nacional mesmo?

CL - É, a gente tentou dar uma abrangência nacional, mas ficou mais ou menos restrita aqui, porque em São Paulo tinha a Comissão Pró-Índio. São Paulo e outros lugares tinham outras entidades que foram criadas. Lá a gente fez um bom trabalho, inclusive quando houve aqueles litígios no noroeste do estado entre índios e, colonos e índios, a gente mediava. Fizemos várias reuniôes, várias idas para lá.

GD - Como é que foi, o Senhor poderia falar um pouco sobre esse conflito que houve em Nonoai, então, entre índios e colonos em [19]78?

$\mathbf{C L}-E$ É, é o seguinte. Aquilo eram áreas, tradicionalmente eram áreas, primitivamente áreas indígenas. Daí no governo do Brizola, o Brizola fez um [assentamento de colonos]. Aí começou: quando o processo de colonização, 
colonos de origem italiana foram se deslocando para lá à procura [de terras], já que a colônia daqui em Caxias [do Sul], isso aí já estava ocupado, já não dava mais oportunidade, as famílias foram se multiplicando e os colonos foram subindo, foram se assentando e cruzando as áreas indígenas. Aí o Brizola, lá pelas tantas, começou a, deu titulação para eles e não sei o que, com que fundamento, e acabou criando lá entáo um conflito. Os índios, reivindicando que a terra era deles, tinha o Parque Estadual também. Então, fizeram uma divisão lá na área de Nonoai, principalmente: tinha o Parque Estadual, que era de preservação, e a área indígena. Mas isto tudo era desrespeitado, porque os colonos também tinham necessidade. Então foi... Era pobre, a gente dizia assim: "era pobre lutando contra miserável”. Era uma coisa terrível! Até [havia] um cacique muito atuante lá, o Xangrê, esse que liderou vários movimentos lá. E havia violência de parte a parte, índio atirando em colono, colono em índio.

CR - E como a Funai [Fundação Nacional do Índio] lidava com isso?

CL - A Funai tinha uns delegados lá, corruptos inclusive, coisa horrível.

CR - Tinha participação de pessoas da região também nesse...

$\mathbf{C L}-\hat{E}$, os políticos, as lideranças políticas em geral. As lideranças políticas se alinhavam com o interesse dos colonos. Vocês só me dáo licença um pouquinho?

CR - Sim, paramos um pouquinho.

Pausa na entrevista

GD - Então, estávamos falando do conflito que houve em Nonoai, em [19]78. Foi um estopim, na verdade, onde os índios começaram a expulsar os colonos da terra.

CR - Vocês chegaram a fomentar entre os índios, ou isso foi, na verdade, uma...

CL - Não, a gente tentava fazer uma conciliação de interesses, não era questão de jogar uns contra os outros. Então, todos estavam em uma situaçáo miserável, os colonos também, não tinha produtividade. 
CR - Já existia algum trabalho da Igreja junto com os índios nessa época? O Cimi [Conselho Indigenista Missionário]?

CL - Já, é, já existia.

GD - Como era essa inserção do Cimi entre os indígenas?

$\mathbf{C L}$ - O problema da Igreja é que na visão tradicional da Igreja é a catequese. E havia também intrusão de seitas evangélicas, protestantes lá, inclusive algumas ligadas a entidades americanas. Havia uma disputa de clientela lá. Isso aí abalava os índios também. Eles ficavam presos àquelas seitas, era uma coisa horrível. Havia até uma denúncia de que havia uma freira que negociava pedras preciosas no meio, era horrível. Isto deve estar relatado, acho que tenho algo sobre isto.

CR - E depois que os colonos foram expulsos, como é que ficou a situação dos índios?

$\mathbf{C L}-\mathrm{Ah}$, até hoje, até há pouco tempo a Hilda Zimmermann, que foi uma companheira na Agapan e na Anaí, e foi muito batalhadora sempre nessa área toda, ambiental e indígena, há pouco, não faz seis meses, ela fez, fizemos um requerimento, ela liderou, para o Ministério Público Federal para reclamar da Funai medidas assim, como área de educação de saúde, vivem em estado de miserabilidade quase absoluta, continua o mesmo processo.

GD - E o governo interveio nesse conflito entre índios e colonos? Para onde foram os colonos?

$\mathbf{C L}$ - Às vezes intervinha, força pública para quando havia um conflito maior.

CR - Era a época do governador Amaral de Souza?

CL - Era.

GD - O governo Amaral de Souza tinha um projeto de encampar reservas indígenas e tutelar os índios, e como é que se dava o...

CL - Eu não lembro muito bem disso, dessas atuaçóes. 
GD - Mas a postura da ditadura em relação aos índios era de tutelar?

CL - Era de tutelar, tanto é que aí veio o episódio do [Cacique Mário] Juruna, que eu já referi, que foi em [19]79, que ia instalar-se em Amsterdam um Tribunal Internacional de Direitos Humanos. E ali eles convidaram o Juruna, Cacique Juruna, que naquele tempo ele ainda não era deputado, mais tarde ele foi eleito deputado, para participar e levar, relatar lá na Europa a situação dos índios brasileiros. E ele pediu - naquele tempo havia um estatuto, os índios eram todos tutelados, ainda são até hoje -, pediu licença para viajar para o país. Pediu licença e aí o General Isnar [Araújo], que era o diretor, o presidente da Funai, negou e, eu não sei se o Isnar negou e o [coronel Mário] Andreazza, que era Ministro do Interior (consulta em livro), não permitiu a saída.

GD - Depois, no final, o Senhor pode falar um pouquinho do livro também, mostrar o livro.

CD - Não, não era, o Isnar veio depois. Não, veio antes, eu acho, esse é o João Carlos Nobre da Veiga, o presidente da Funai. Ele chegou a prometer o passaporte para o Juruna para viajar, mas aí o Mario Andreazza, que era Ministro do Interior, a quem a Funai era submetida, negou, disse que o índio era tutelado, e já que a Funai também não era convidada, ele também não podia ir...

GD - Tentou abafar as discussóes.

CL - E negou a licença. Foi quando eu, daqui, entrei com um telegrama junto ao Tribunal Federal de Recursos, que é o antecessor desse atual Superior Tribunal de Justiça, com um habeas corpus para que fosse autorizada a ida dele. Sem muita fé, porque a justiça também estava muito dominada, não havia garantias, os juízes estavam sem garantias, estabilidade, podiam ser cassados também. Aí o processo andou e, inclusive outros deputados, um do Rio, outro da Paraíba, entraram com mandado de segurança. Eu sei que no dia do julgamento eu fui lá, e eu sustentei justamente, o fundamento era na Convenção Internacional de Direitos Humanos, que dava garantias de direito de ir e vir para os índios, povos indígenas. Aí eu fui lá sem muita esperança, meu processo entrou em pauta, só que ao invés de entrar o meu 
habeas corpus, entrou pelo regimento interno, os mandados de segurança dos outros, que entraram na frente. Mas a tese era a mesma que eles sustentavam. Eu não tinha muita fé, mas o relator era o ministro Washington Bolívar, uma surpresa até que eu tive: que ele tinha sido da Casa Civil do governo Médici e foi nomeado pelo Médici para ministro. Eu digo: "esse cara aí é ligado ao regime militar". Mas, sabe, que quando ele começou a analisar todo esse acórdão - esse voto dele, deve estar na revista do Tribunal Federal de Recursos, eu náo tenho aqui -, ele começou a analisar toda a saga dos povos indígenas, desde o chamado Descobrimento, até... Fez uma análise profunda, e terminou dizendo assim: "aqueles que sempre foram dominados, espoliados e vencidos nesse país, esta noite sairão vencedores. Concedo a ordem para o Cacique Juruna viajar". Eu chorei até, foi uma coisa magnífica isto. Daí ele foi para lá, chegou e o Tribunal já tinha sido instalado, mas foi recebido. Depois, mais tarde, o Juruna se elegeu a deputado federal, foi o primeiro índio.

CR - Ele se elegeu em [19]82?

$\mathbf{C L}-[19] 82$.

CR - E ele era liderança de alguma organização indígena, além de ser cacique?

CL - Não, ele representava o povo do Xingu, ele era xavante. Ele era do Xingu. Mas ele estava sempre... Agora, antes disso, a gente vivia, se formou assim uma espécie de grupo tripartite, que era a OAB, o Cimi, os bispos...

\section{GD - CNBB?}

$\mathbf{C L}-$ É, a CNBB, e os antropólogos do Rio, São Paulo. E a gente se reunia várias vezes em São Paulo, em conventos dominicanos, a gente ia para lá em reunióes, e aí vinham os caciques todos. Então, ali se fazia um brain storm assim, se discutiam os problemas que os índios traziam, a gente conversava e tal. Passávamos às vezes dois, três dias, uns hospedados no convento dominicano. Foi o convento em que o Marighella foi fuzilado ali perto. Isso aí frutificou. Hoje você pode ver que abriu um espaço muito grande para os índios, principalmente daqueles de lá. Eles têm acesso [à universidade], eles 
têm índios formados em direito, medicina. Eles foram se conscientizando, assumindo. O nosso papel não era de tutelar também, era de, justamente, abrir espaço para eles assumirem a sua própria identidade.

CR - E havia setores da Igreja Católica, mais progressistas, que não tinham essa visão só de catequizar os índios?

$\mathbf{C L}-$ É, não, essa turma não tinha [essa visão]. Até hoje existe o Dom Tomás Balduíno, aquele bispo de Goiás Velho e outros, não me lembro agora dos nomes, o Dom Tomás Balduíno, tinha um bispo lá de Bauru. Havia vários bispos e padres que tinham uma visão muito aberta. Tinham e têm.

CR - E com os Sem Terra, o Senhor tinha algum contato? Com os acampados da Encruzilhada Natalino, e depois com os da Fazenda Annoni? ${ }^{10}$

CL - Não, eu não tive muito contato, eu estava tão empenhado nessa questão indígena. Eu tinha uns amigos, inclusive da procuradoria, Doutora Rejane Brasil Filippi - depois mais tarde ela foi delegada do Ibra [Instituto Brasileiro de Reforma Agrária], do Incra [Instituto Nacional de Colonização e Reforma Agrária], e ela atuou mais nessa questão.

GD - E existia alguma entidade indígena chamada UNI, União Nacional dos Índios?

CD - Eu acho que sim.

GD - Mas não tem mais...

$\mathbf{C L}$ - Era tudo, a gente tinha um trabalho conjunto. Havia muita...

GD - Vocês na Anaí... (Caio faz sinal pedindo uma pausa).

10 Trata-se de dois importantes acampamentos de agricultores Sem Terra que foram organizados no Rio Grande do Sul na década de 1980. Sobre o tema, ver MARCON, Telmo. Acampamento Natalino História da luta pela reforma agrária. Passo Fundo: Ediupf, 1997; HOFFMANN, Leandro S. N. A cruz e a bandeira: a construção do imaginário dos sem-terra do Rio Grande do Sul - 1981/1987. Porto Alegre: UFRGS, Dissertação de Mestrado em História, 1997; e ROSA, Marcelo Carvalho. "Sem-Terra: os sentidos e as transformaçóes de uma categoria de ação coletiva no Brasil”. Lua Nova [online]. 2009, n.76, p. 197-227. 


\section{[Pausa na entrevista]}

CL - O caso do Juruna, um aspecto interessante, o ministro Mário Andreazza era de uma família lá de Caxias [do Sul], família muito amiga nossa, e ele, inclusive, foi colega do meu irmão no IPA, no curso secundário. Mas eles não adotaram nenhuma medida de represália contra mim.

CR - Aceitaram o Senhor.

$\mathbf{C L}-\hat{E}$, aceitaram.

CR - Aí o Juruna foi e fez bonito lá.

CL - Participou, fez bonito. O argumento deles é que o Juruna ia difamar, sujar o nome do país no exterior.

CR - Eles tinham muito medo disso, que no exterior se dissesse...

CL - Que fosse manchar o nome do país.

GD - E vocês sofreram uma... Atuando na Anaí vocês sofreram alguma ameaça do governo pela atuação de vocês?

CL - Que eu me lembre, não. De vez em quando vinham uns avisos: "Ah, vocês se cuidem, porque..."

CR - A Anaí participou das campanhas pela anistia? Que lembranças o Senhor tem desse período?

$\mathbf{C L}-E$ É, a gente militava nessa... É que neste tempo não havia partido [político]. A gente militava tanto na Agapan como na Anaí, e outros, movimento da anistia e tudo isso.

CR - Tem alguns nomes, alguém que tenha se destacado nessas campanhas pela anistia? Ou algum episódio que o Senhor lembre?

CL - Eu me lembro da... Eu, a essa altura, era vereador, eu fui eleito vereador em [19]82, e me lembro da presença de Teotônio Villela, em que ele lançou 
até o Projeto Esperança. Ele veio aqui, ele já estava doente, mas participou ativamente aqui na...

CR - Isso quando o Senhor já era vereador?

CL - É.

CR - Tá, mas um pouquinho antes, antes de [19]79, o Senhor tem lembrança de mobilizaçóes aqui em Porto Alegre em prol da anistia?

$\mathbf{C L}$ - É, havia muitas reuniōes da $\mathrm{OAB}$, principalmente. Havia o presidente da OAB, o advogado Justino Vasconcellos. E mais tarde, isso já foi em meados de [19]80, antes da [Assembleia] Constituinte, houve um Congresso para apresentar um projeto de constituição. Desse eu participei.

$\mathbf{C R}-\mathrm{Da} \mathrm{OAB}$ ?

CL - É, da OAB, eu era do Instituto dos Advogados também, e eu participei disso. E inclusive a parte que redundou nesses artigos da Constituição [de 1988] sobre a questão ambiental e indígena, eu fui coordenador dessa parte. O congresso chamou Congresso Pontes de Miranda, era em [19]85, [19]86, por aí.

CR - E quando houve a reforma partidária, o Senhor participou da criação do PT? O Senhor foi vereador pelo PT?

CL - Não. Foi assim: eu fui eleito depois que houve a abertura. Aí começou a haver a abertura, aí se formaram... Bom, o regime militar tinha criado dois partidos, a Arena e o MDB: um era o "sim", o outro era o "sim, senhor". Era uma oposição consentida, mas era o que havia, e eu ingressei no MDB. Depois, fui candidato por força do movimento ecológico ambientalista, o pessoal me... Inclusive o Jair Krischke participou ativamente da minha eleição. ${ }^{11}$ A essa altura também já participava do Movimento Justiça e Direitos Humanos, ajudei a fundar junto com o Jair e outros, e daí ...

11 O entrevistado, aqui, refere-se a um dos fundadores do Movimento de Justiça e Direitos Humanos no Rio Grande do Sul. 
GD - Mas o Senhor foi ser candidato após o pluripartidarismo ou na década de [19]70?

CL - Não, pelo PMDB.

GD - Já era PMDB.

CL - É, já era PMDB. Eu fui vereador pelo PMDB de [19]83 a [19]88. E nesse período até, acho que ali por, parece que [19]86, aquele poeta, Thiago de Mello, veio até nós - ele tem até um poema em homenagem àquele sargento, Raimundo Soares, que foi... ${ }^{12}$

GD - O caso das mãos amarradas.

CL - O caso das mãos amarradas. Então, o Thiago veio aqui e fez até uma homenagem lá na beira do rio, tem uma foto dele aqui (folhando o livro), e a gente fez uma homenagem para o sargento Raimundo, completava não sei quantos anos do assassinato dele.

CR - E a sua atuação como vereador, como foi? O que o Senhor destacaria desse período? Que tipo de açóes, de projetos que o Senhor propôs?

$\mathbf{C L}$ - Bom, eu tive uns projetos. Deixa eu ver, o mais importante deles foi um projeto que eu coordenei, foi de um grupo imenso de entidades, que era de tombamento do patrimônio natural, artístico e histórico da cidade, e já compreendia o tombamento por lei de, vamos dizer, dos morros paisagísticos, prédios históricos, tudo mais. Esse projeto foi no governo do [Alceu] Collares. ${ }^{13}$ A Câmara aprovou com... Nós não tínhamos a maioria, a Câmara aprovou, mas com restriçóes. Inclusive, a gente queria era tombar por lei, porque o tombamento pode ser feito por lei ou por decreto, nós queríamos amarrar por lei para ficar mais. Eles não toparam. Mesmo assim, o Collares vetou o projeto porque ele disse que era contrário ao interesse público,

12 Caio Lustosa está se referindo ao sargento Manuel Raimundo Soares, que foi preso e morto em dependências policiais em 1966. Seu caso ficou conhecido como o \caso das mãos amarradas $\bigotimes$, pelo fato de o corpo do sargento ter sido encontrado boiando no Rio Jacuí com as mãos amarradas, dias após ter sido liberado da Ilha do Presídio. Ver: Rodeghero, Dienstmann e Trindade. Op. cit.

13 Alceu Collares, do PDT, foi prefeito de Porto Alegre de 1986 a 1989. 
quando era justamente o contrário disso, e por isso até ele foi agraciado por um instituto lá do Peru de patrimônio histórico como o prefeito mais contrário à preservação histórica. Ele recebeu o prêmio Átila, até tem uma crônica do Luís Fernando Veríssimo sobre isso. Bom, esse projeto ele vetou total. Aí, na outra legislatura, um vereador pegou o projeto e apresentou e hoje é essa lei que tem aí de patrimônio que foi bem desfigurada do projeto inicial, mas de qualquer forma, a lei municipal essa, é fruto do nosso trabalho. Outra coisa que eu fiz foi uma investigação sobre o projeto do Rio Guaíba, de despoluição do rio.

GD - Uma CPI?

CL - Uma CPI que apurou todas as falcatruas dos governos do [Guilherme Socias] Villela e o [Antônio Augusto] Amaral de Souza. ${ }^{14}$ Em [19]81 eles disseram que iam despoluir o [Rio] Guaíba em cinco anos, prorrogaram por mais cinco. Quando eu cheguei na Câmara, em [19]86, já se haviam passado cinco anos e as condiçóes estavam cada vez piores. Eles tinham gasto milhóes de dólares lá que o Delfim Neto liberava, mas foi tudo parar no bolso das empreiteiras, e não fizeram uma estação de tratamento. Agora [é] que estão fazendo, mas foi um desperdício, assim, enorme, ele inclusive pediu que a justiça chamasse esse pessoal, mas aquele tempo o Ministério Público estava muito omisso, deu em nada.

GD - E na década de [19]80...

CL - Fiz outro projeto de condutores de cargas perigosas dentro da cidade, de transporte e armazenamento de cargas perigosas dentro da cidade.

CR - Vocês davam sustentação ao governo do Collares? Ou havia muita...

CL - Não.

CR - Não, vocês não eram a base dele?

14 Guilherme Socias Villela, da Arena e depois do PDS, foi prefeito de Porto Alegre de 1975 a 1983. Antônio Augusto Amaral de Souza, da Arena e depois do PDS, governou o Rio Grande do Sul de 1979 a 1983. 
$\mathbf{C L}$ - Eu, por exemplo, eu e um grupo de colegas, a bancada do PMDB, era assim, eram 11 do PMDB, 11 do PDT e o PDS, a [antiga] Arena, e o PFL eram minoritários, tinha mais o PCB com o Lauro Hagemann, o PC do B, com a Jussara Cony, e o PT, com Antônio Holfeldt, mas nós não tínhamos maioria, porque logo o Collares se uniu com essa direita toda e daí eles conseguiam se entender bem (risos). Eu tinha sido, inclusive, colega de turma do Collares, colega e eleitor nos primeiros mandatos deles para vereador aqui. Aqui em casa mesmo faziam reunião de... Um dia, numa reunião, a gente teve um debate. Ele [disse]: "É, mas a Dona Araci - que é minha mãe - sempre me apoiou”. Eu digo: "É, mas quando você era diferente" (risos).

CR - Nesse período dos anos [19]80 também há muito agitação sindical, a fundação da CUT, da CGT. O Senhor teve algum contato com esses movimentos?

CL - Não, eu sempre tive grandes companheiros no movimento sindical, em geral eram comunistas, socialistas, porque havia muita pelegagem. Nos anos [19]60 era uma pelegada, inclusive que se alinhava com Brizola, com Jango e com o PTB, mas muito oportunismo, muita... Os mais consequentes líderes sindicais que eu conheci, inclusive, Roque Cruz Vargas, [Álvaro] Ayala, que era da energia elétrica, o Campesato, todos esses eram pessoas autênticas e tinham compromisso mesmo com a classe operária, mas havia muito pelego, oportunistas, aproveitadores. Então, eu sempre tive uma espécie de, não era restrição, eu tinha...

\section{CR - Aversão?}

CL - É, ficava meio, preconceito com certas lideranças. Há um episódio que faltou contar aqui e que foi, deixa-me ver, logo depois de [19]64. O pai do Carlos Araujo, o Afrânio de Araujo, que tinha sido do PCzão e não sei se estava no PC do B, me chamou, eu era funcionário do tribunal, que eu trabalhei lá como secretário de Câmara, mas eu queria sair para advogar. Não queria ficar naquela burocracia, daí o Afrânio soube disso e disse: "Tem um lugar para ti, você quer ser advogado do sindicato dos mineiros, lá em Criciúma?", Eu disse: “quero". Aí rumei para lá, o advogado dos mineiros lá tinha sido banido pelos militares porque trabalhava muito contra os patrôes, os mineradores. Então, foi chutado de lá, saiu perseguido. Aí, 
cheguei lá, falei com os dirigentes do sindicato, me receberam, me alojei em um hotel, levei só livro jurídico. Naquele tempo eu não tinha, logo em [19]65 por aí, não tinha condição de fazer proselitismo político, até aí tudo bem. Aí os dirigentes me levaram para conhecer as minas de carvão lá, a situação terrível daqueles mineiros trabalhando com água pela cintura, e o delegado do Ministério do Trabalho era um lacerdista tricomprometido com os patróes, liberava aquele trabalho assim, morava em uma mansão igual às dos donos das minas, e o líder dos mineradores, dono das minas, era um tal de Freitas, depois veio a ser deputado federal. Aí nós percorremos lá, no primeiro dia fui lá no sindicato, tinha uma fila assim, como daqui até aquela esquina (aponta) de mineiros que estavam carentes de assistência judiciária. Era problema de saúde, salários, tudo, todos os direitos trabalhistas negados há mais de um ano, dois anos. Aí eu quase que me assustei, vou ter que trabalhar que nem um louco, mas nem deu para esquentar o banco, porque dois dias depois o presidente do sindicato disse: "Olha, o Senhor não pode ficar aqui. Nós recebemos ordens dos donos das minas, que o Senhor é um elemento trissubversivo, que o Senhor veio para aqui agitar os operários contra os donos das minas, entâo o Senhor tem que... Náo podemos, porque eles disseram que se o Senhor ficar, eles vão lhe prender, vão prender a nós e fechar o sindicato".

GD - Isso em que ano?

CL - [19]65, [19]66, por aí, é, foi antes de eu fazer concurso. Aí eu digo: "Bom, se é assim, vou embora". Aí, um ano depois, um amigo meu, que tinha sido companheiro no... Era advogado aqui, encontrou com esse empresário, Freitas, lá em Morro dos Conventos, e disse: "Como é que vocês correram com o meu amigo que era advogado do sindicato?". [Freitas respondeu:] "Ah, náo podíamos permitir que ele ficasse aqui porque ele nos causava muito problema”, e esse meu amigo então descobriu que quem tinha me delatado para esse pessoal era um advogado deles que tinha sido meu contemporâneo aqui, só que era da PUC, me conhecia, minha atuação, aí me entregou e com isso eles me deram um cartão azul, cartão vermelho (risos).

GD - E na década de [19]80, com a redemocratização, houve um impulso na luta por questóes ambientais? Houve uma maior... 
$\mathbf{C L}$ - É, houve, nós fizemos muita manifestação, inclusive a questão da energia nuclear, sempre havia, problemas não faltavam.

CR - Era um movimento que congregava muitas pessoas? Assim, quando vocês promoviam alguma coisa, tinha público?

$\mathbf{C L}-E$, tinha, havia bastante receptividade. Teve uma luta aí sobre a questáo da poluição do Rio Gravataí, Banhado Grande, essa coisa toda. Uma lá da Lagoa dos Patos, lá em Tapes, que havia uma firma, uma multinacional, que queria se instalar lá para extrair areia para fabricaçáo de vidros. Aí a populaçáo lá começou a se rebelar e nos pedir apoio. Teve outro episódio, lá em Bom-Será, ali na beira do Rio Camaquá, perto de Encruzilhada [do Sul] e Camaquá, que era uma barragem que queriam fazer, imagina, uma barragem para a acumulação de água para os arrozeiros, grandes arrozeiros, barragem Bom-Será.

\section{CR - Montserrat?}

$\mathbf{C L}$ - Bom-Será. E ela ia desalojar mais de mil famílias de agricultores em benefício de vinte ou trinta grandes arrozeiros, foi uma luta muito boa, inclusive com a Igreja, é isso.

CR - O Senhor falou que contribuiu para que no texto da Constituição de [19] 88 tivesse artigos referentes à questão ambiental. Como é que o Senhor viu a Constituinte e a Constituição de [19]88?

$\mathbf{C L}$ - É, teoricamente ela é boa. O problema é a aplicação, aliás, uma coisa que eu esqueci de relatar foi a campanha, que agora está recrudescendo, para a elaboração de uma legislação de controle dos agrotóxicos. Isso aí foi um trabalho muito bom que a gente fez. Eu assessorei a parte jurídica da primeira lei estadual de agrotóxico. Foi aqui no estado, porque com aquele surto do plantio de soja dos anos [19]60 em diante, e o uso desses venenos agrícolas de insumos, que eram intensivos, começaram os problemas de saúde de agricultores por todo o estado, e daí a gente se mobilizou, o Lutzenberger como era perito nisso, tinha trabalhado em multinacional dos venenos na Alemanha, [a BASF], e foi um dos motivos que ele teve uma crise de consciência e saiu da multinacional dos venenos e veio criar a Agapan. Então ele, na parte técnica, e outros companheiros aí, o Flávio Lewgoy, que era do Instituto de Biologia 
da UFRGS, e outros, Milo Raffim, um pessoal de Pelotas, que tinha o centro de estudos toxicológicos, a gente se juntou e partimos para a elaboração da primeira lei, foi a lei pioneira no Brasil, primeira lei estadual. Dessa lei estadual decorreu depois a lei federal, que é a atual Lei Nacional de Controle dos Agrotóxicos. Agora, o problema é que nunca se usou tanto [agrotóxico]. Até que agora saiu um documentário do Silvio Tendler: "O veneno está na mesa”. Passou no Cine Bancários, eu acho que tem no site dele.

GD - Eu ouvi falar.

$\mathbf{C L}-\mathrm{O}$ consumo de agrotóxicos pelos brasileiros é de quase seis quilos por habitante/ ano, que se consome nesses produtos todos, industrializados, farinhas, produtos agrícolas todos. E agora se formou uma frente lá que está tentando, o problema todo é que a grande, o chamado agronegócio, vive na base desses insumos. Eles, para produzir bastante, para ter bastante produtividade, então o combate às pragas deles, ao invés de ser de uma forma equilibrada, é assim, na base desses venenos.

GD - E a sua atuação como Secretário do Meio Ambiente? Foi na prefeitura do Olívio [Dutra] ? $^{15}$

CL - Bom, é. Dentro dessa linha sobre a visão dos agrotóxicos, nós elaboramos um decreto que o Olívio assinou contra a chamada "dúzia suja”, porque existem doze agrotóxicos que são altamente prejudiciais, cancerígenos, causam problemas de tudo o que é jeito, e nós fizemos um decreto em que ele proibia, é claro, nos limites de Porto Alegre, o uso, a comercialização, o transporte desses produtos. Claro que as multinacionais entraram na justiça e conseguiram derrubar o nosso decreto, mas esse decreto foi pioneiro no mundo inteiro. Só dez anos depois que a Organização Mundial da Saúde listou esses doze produtos e estáo proibidos em nível de Europa e dos Estados Unidos. Isso foi dez anos depois que a gente... Os cientistas já haviam denunciado isso no mundo inteiro, tanto é que por isso nós fizemos o decreto, mas os organismos internacionais ainda não tinham, a Organização Mundial da Saúde não tinha reconhecido. Só dez anos depois do nosso decreto, apesar de ele ter caído, mas pelo menos ele foi um marco.

15 Olívio Dutra, do Partido dos Trabalhadores, foi prefeito de Porto Alegre entre 1989 e 1992. 
GD - E na década de [19]90, o Senhor atuou como promotor?

CL - Não.

GD - Que outra ação o Senhor teve?

CL - Eu fiz concurso para advogado de ofício, que é hoje defensor público, e depois, mais tarde, quando separaram a Defensoria Pública da Procuradoria, eu passei a ser procurador do estado.

CR - E se aposentou como procurador?

$\mathbf{C L}-E$ É, me aposentei como procurador. Outra luta que nós tivemos boa, foi do Parque de Itapuá, que foi uma luta também muito séria, ali nos anos [19]76. Com o respaldo do governo [Sinval] Guazzelli, na época, tinha um grupo, não ele, na época, mas a "entourage", tinham colocado dentro do Parque de Itapuã uma firma do Rio de Janeiro para explorar o granito rosa, que é uma pedra que na Europa não tem mais. ${ }^{16}$ Aí queriam explorar para exportar, aí o Lutzenberger fez todo um bolo, e uma das coisas que me queimava na Procuradoria era por isso, porque eu tinha atuação lá dentro, e tinha atuação fora, nos movimentos. Com isso, eu nunca tive cargos de chefia, promoção, promoção era só por antiguidade, merecimento, eu nunca mereci nada, então era assim. Conseguimos fazer uma luta, e eu era encarregado do processo judicial de desapropriação da área do parque. Aí, um dia, eu denunciei para o governador [através do jornal Correio do Povo]. Era tão grande essa firma lá, e quebrando aqueles, se for hoje lá no Parque Itapuã dá para ver umas pedras que estão rompidas que eles explodiam, conseguimos salvar muita coisa, mas aí eu botei a boca no trombone, fui para o jornal e denunciei que o governador, que era o Guazzelli, deveria ir lá e ver, mas sorte que eu havia conseguido de um juiz lá de Viamão, na época, uma ordem judicial mandando parar com a extraçáo, e depois, futuramente, se implantou o parque.

GD - Bom, o Senhor já atua há quarenta anos na luta em defesa do meio ambiente. Como é que o Senhor vê essa luta hoje, assim... Que desafios?

16 Sinval Guazzelli, da Arena, foi governador do Rio Grande do Sul entre 1975 e 1979. 
CL - O Lutzenberger costumava dizer que "as nossas vitórias são efêmeras e que as nossas derrotas são permanentes”, e é isso. Hoje, a coisa tem esses problemas aí dessas grandes barragens, Belo Monte, no Rio Uruguai, esse problema da usina Nuclear de Angra, de Angra 2, Angra 3. A verdade é que a visão desses governos todos aí, o governo, vamos ficar nesses dois últimos aí, o Lula e a Dilma, eles têm uma visão tecnocrática. Então, eles têm uma visão de desenvolvimento, de crescimento a todo custo, o negócio é produzir, o país precisa de energia, investe na indústria automobilística, investe nessa especulação imobiliária nas cidades, esse horror. Ainda ontem, o Olívio [Dutra] estava lá na Câmara [Municipal de Porto Alegre] falando sobre a questão da regularização fundiária. Ele foi Ministro das Cidades também, ele disse que, infelizmente, a lógica desse sistema é em cima da indústria automobilística, a indústria automobilística é que manda no desenvolvimento, desenvolvimento não, entorpecimento das cidades. Se vê hoje os carros atulhando, cada vez mais montadora, cada vez mais. A indústria automobilística de um lado e a especulação imobiliária, os grandes grupos imobiliários, condomínios de luxo e tudo. Então, isso é uma visão de... Isso tudo financiado com recursos públicos. Então, essa visão é o que a gente sempre combateu.

GD - Como que o Senhor vê a forma como estão sendo tratados os crimes da ditadura hoje em dia no Brasil? Como o Senhor vê esse processo? A Comissão da Anistia?

CL - Houve a promulgação da Comissão da Anistia [da Verdade], eu acho que é melhor que nada, mas...

CR - Comissão da Verdade, o Senhor quer dizer?

$\mathbf{C L}$ - É, Comissão da Verdade eu quis dizer.

GD - Da Anistia é anterior.

CL - Mas, o que acontece, é que vai apenas, se chegarem a um termo, é botar na vitrine os torturadores. Isso todo mundo já sabe quem são, já tem relatórios do "Tortura nunca mais", não sei qual é...

CR - O Senhor não acha que é esse o caminho, então? 
CL - Não, eu acho que, os outros países, por exemplo, o Uruguai e a Argentina, eles anularam aquelas leis de, de...

GD - De anistia.

CL - ...anistia, e estão processando e julgando os criminosos lá, porque a minha tese e de outros é que esse crimes de tortura são imprescritíveis. Aí é que nosso Congresso aprovou essa Lei de Anistia e o Supremo reconheceu que tem que ser aplicada. Só uma outra, uma Constituinte que viesse a reformular isso. Acontece que não há, digamos assim, no imaginário do povo, uma consciência popular, isso não é uma demanda, a não ser dos grupos diretamente interessados nisso, pró ou contra, não há uma sensibilização nacional em relação a isso.

CR - Será que o funcionamento dessa Comissão não vai ajudar nessa sensibilização?

CL - Talvez isso sensibilize futuramente um novo Congresso. Desse Congresso que está aí não sai nada. Um novo Congresso, e para mim só uma [Assembleia] Constituinte, outro [Congresso] exclusivo é que poderia modificar isso.

CR - E medidas como indenização a perseguidos políticos, o que o Senhor acha em relação a isso?

$\mathbf{C L}-\mathbf{E}$, resistente de certa forma, porque não há dinheiro que pague essas vidas que foram perdidas, sacrificadas, mas é um consolo.

CR - Sim, o Senhor tem um livro? O Senhor poderia nos falar um pouco sobre o livro? Mostrar ele para a câmera, diga como é que tomou essa iniciativa de escrevê-lo.

CL - Esse livro aqui é uma condensação dos, conforme o próprio título (mostra a capa para a câmera): "A luta ambiental e cidadania" foi escrito juntamente com uma jornalista, Eva Benites.

GD - Como é que foi o processo de escrita? 
CL - (Lê o subtítulo) "Da Borregaard e outros episódios”. Então, a partir da Borregaard, todos esses episódios que eu tive participação direta estão relatados aqui.

GD - Quanto às questóes ambientais, desde o início da luta ambiental.

$\mathbf{C L}$ - Desde o caso da Borregaard, que é o primeiro vai...

CR - O Senhor tinha muitos registros? Papéis? Jornais?

$\mathbf{C L}-$ É, eu tenho muitos arquivos, uma hemeroteca imensa, até botei ali na área, então guardo muito essas... Também tinha os anais da Câmara e os discursos, os pronunciamentos que eu fiz, essa coisa toda.

CR - Qual é a importância de fazer isso ou de dar um depoimento?

CL - É bom, pelo menos fica o registro de certas coisas, muitas vezes a população e a imprensa não dáo o devido destaque.

GD - Qual a importância que o Senhor vê em resgatar a memória destas lutas democráticas, desse período de...

CL - Qual a importância que eu dou?

GD - É, que o Senhor vê em dar um depoimento, em escrever um livro.

CL - Eu acho que é importante o registro de todos esses episódios, da Legalidade, esses episódios relativos à questão ambiental, tudo isso é importante para as novas geraçóes, é o acúmulo de experiências de história para as geraçôes presentes e futuras, acho que é muito válido.

GD - Como foi a experiência de participar de uma entrevista, o Senhor já havia participado antes?

CL - Foi muito gratificante, eu agradeço essa iniciativa.

GD - Nós que agradecemos a disponibilidade.

CR - Muito obrigado. 
GD - E, só para finalizar, o Senhor tem alguma, hoje em dia o Senhor atua em algum partido político, alguma entidade?

CL - Eu estou filiado ao PSOL, que depois daquele caso do mensalão eu desisti do PT.

CR - Ok. Muito obrigada.

GD - Muito obrigado, agradecemos muito o depoimento.

\section{Referências}

BENITES, Eva; LUSTOSA, Caio. Luta ambiental e cidadania: da Borregaard a outros episódios. Porto Alegre: Livraria Palmarinca, 2011.

CHAISE, Sereno; KLÖCKNER, Luciano. O diário politico de Sereno Chaise: 60 anos de história. Porto Alegre: AGE, 2007.

HOFFMANN, Leandro S. N. A cruz e a bandeira: a construção do imaginário dos sem-terra do Rio Grande do Sul - 1981/1987. Dissertação de Mestrado. UFRGS. Porto Alegre, 1997.

LUSTOSA, Caio. Entrevista concedida a Carla Simone Rodeghero e a Gabriel Dienstmann, em 22 de novembro de 2011, em Porto Alegre, RS, para o Projeto Marcas da Memória: História Oral da Anistia no Brasil.

MARCON, Telmo. Acampamento Natalino - História da luta pela reforma agrária. Passo Fundo: Ediupf, 1997.

RODEGHERO, Carla S.; DIENSTMANN, Gabriel; TRINDADE, Tatiana. Anistia ampla, geral e irrestrita: história de uma luta inconclusa. Santa Cruz do Sul: Editora da Unisc, 2011.

ROSA, Marcelo Carvalho. Sem-Terra: os sentidos e as transformaçôes de uma categoria de ação coletiva no Brasil. Lua Nova [online]. 2009, n.76, p. 197-227.

Resumo: A trajetória do advogado e ambientalista Caio Lustosa é apresentada na entrevista que ele concedeu ao Projeto Marcas da Memória: História Oral da Anistia no Brasil, em novembro de 2011. O relato oferece um panorama do surgimento, na década de 1970, dos novos movimentos sociais, com destaque para a luta ambiental e a questão indígena, e revela também uma rica militância política que começa com as campanhas nacionalistas do pré-golpe e avança até as lutas ambientais contemporâneas. 
Palavras-chave: Caio Lustosa, meio ambiente, índios, ditadura, política.

\title{
Decades of activism: politics and the Environment in a Caio Lustosa's interview
}

\begin{abstract}
The trajectory of the lawyer Caio Lustosa it's presented in the interview that he granted to the Project Traces of the Memory: Amnesty Oral history's in Brazil in November of 2011. The report offers an overall picture of the emergence of the new social movements in the seventies, with emphasis on the environmental struggle and the Indian movements. It reveals a rich political militancy that begins with the nationalist campaigns from the fifties and sixties' and advances until the contemporary environmental movement.
\end{abstract}

Keywords: Caio Lustosa, Environment, Indians, dictatorship, politics.

Recebido em: 05/08/2012

Aprovado em: 30/08/2012 